\title{
ANTIOXIDANT CAPACITY, ANTHOCYANINS, AND TOTAL PHENOLS OF WILD AND CULTIVATED BERRIES IN CHILE
}

\author{
Jaime Guerrero C. ${ }^{*}$, Luigi Ciampi P. ${ }^{2}$, Andrea Castilla C. ${ }^{1}$, Fernando Medel S. ${ }^{2}$, Heidi Schalchli S. ${ }^{3}$, \\ Emilio Hormazabal U. ${ }^{3}$, Emma Bensch T. ${ }^{1}$, and Miren Alberdi L. ${ }^{3}$
}

\begin{abstract}
It is possible to incorporate a lot of natural antioxidants into the human organism by consuming berries which can prevent diseases generated by the action of free radicals. Antioxidants neutralize free radicals and thus protect the organism from the oxidative damage of lipids, proteins, and nucleic acids. Berries stand out as one of the richest sources of antioxidant phytonutrients among various fruits and vegetables. The objective of this research was to determine antioxidant capacity (AC), total anthocyanins (TA), and total phenols (TP) of wild and cultivated berries in different localities of La Araucanía and Los Ríos Regions in Chile. These parameters were analyzed by using the free radical 2,2-diphenyl-1-picrylhydrazyl hydrate (DPPH) method, pH-differential, and Folin-Ciocalteu method. Percentages of DPPH discoloration of different berries studied were between $67.8 \%$ and $95.3 \%$ for red sarsaparilla and rosehip, respectively. Maqui berries showed a significantly higher TA content (2240.2 and $1445.3 \mathrm{mg} \mathrm{L}^{-1} \mathrm{cyanidin}$ 3-glucoside) than other berries, and a mean for all berries of $335.5 \mathrm{mg} \mathrm{L}^{-1}$. Higher phenol content levels were obtained in two cultivars of saskatoon (773.9 and $1001.9 \mathrm{mg} \mathrm{L}^{-1}$ gallic acid) and wild rosehip (1457.0 and 1140.4 $\mathrm{mg} \mathrm{L}^{-1}$ gallic acid). We conclude that there are significant differences in antioxidant capacity of wild and cultivated Chilean berries in this study which show a strong correlation between AC and TP content.
\end{abstract}

Key words: 2,2-diphenyl-1-picrylhydrazyl, Vaccinium corymbosum, antioxidant potential.

\section{INTRODUCTION}

Plant tissues, especially fruits and vegetables, contain many different chemical compounds with different biological and pharmacological capacities and properties. The most common phytochemical antioxidants include ascorbic acid (vitamin C), tocopherols and tocotrienols (vitamin E), carotenoids (provitamin A), and phenolic compounds such as phenolic and flavonoid acids (flavones, isoflavones, flavanones, anthocyanins, and catechins) (Hertog et al., 1993; Cao et al., 1996; Wang et al., 1996; 1997; Prior et al., 1998; Zheng et al., 2003; Roberts and Gordon, 2003; Su and Chien, 2007; Seeram, 2008a; Speisky et al., 2008).

\footnotetext{
${ }^{1}$ Universidad de La Frontera, Facultad de Ciencias Agropecuarias y Forestales, Casilla 54-D, Temuco, Chile. "Corresponding author (jguerre@ufro.cl).

${ }^{2}$ Universidad Austral de Chile, Facultad de Ciencias Agrarias, Casilla 567, Valdivia, Chile.

${ }^{3}$ Universidad de la Frontera, Facultad de Ingeniería, Ciencias y Administración, Casilla 54-D, Temuco, Chile.

Received: 17 August 2009.

Accepted: 15 March 2010.
}

Vegetable, fruit, and cereal consumption in the diet has been promoted because of its reported benefit to human health, especially in the prevention of degenerative diseases. Research studies carried out on this topic indicate that free radicals cause oxidative damage to lipids, proteins, and nucleic acids (Prior et al., 1998). It is also mentioned that they are associated to cancer, cardiovascular, and neurodegenerative diseases (Hollman and Katan, 1999). Accordingly, antioxidants are important in neutralizing these free radicals and thus prevent diseases (Gil et al., 2002). The effective protection exerted by plants on degenerative diseases has been widely reported (Prior et al., 1998; Seeram et al., 2006; Halliwell, 2007; Seeram, 2008b).

Growing interest in the role of antioxidants in human health has triggered intense research in the field of agronomic and food sciences. Recently, studies have been devoted to determining how the content and activity of these compounds can be maintained or improved through cultivar development, production practices, postharvest storage, and plant processing. Moure et al. (2000) also maintain that it is a priority to replace these synthetic substances with natural ones, which is why the search 
for this type of new plant products has been intensified for their use in the food, pharmaceutical, and cosmetic industry.

Studies carried out by Kähkönen et al. (2001) in 26 samples of berries of the family Ericaceae genus Vaccinium; family Rosaceae genus Rubus; and family Grossulariaceae genus Ribis demonstrate a high variation in total phenol content among evaluated berry genera and species. Along the same line, in their study of antioxidant potential of five types of berries, Wada and Boxin (2002) indicate that the antioxidant capacity varied between 24 and $2 \mu \mathrm{mol}$ Trolox eq $\mathrm{g}^{-1}\left(\mu \mathrm{mol} \mathrm{TE} \mathrm{g}^{-1}\right)$ of fresh weight among species, anthocyanins between 0.65 and $5.89 \mathrm{mg}$ $\mathrm{g}^{-1}$, and total phenols between 4.95 and $9.80 \mathrm{mg} \mathrm{g}^{-1}$. They concluded that the high antioxidant capacity recorded for some of these berries was positively correlated with the high total anthocyanins and phenol content.

Techniques based on spectrophotometry, high performance liquid chromatography (HPLC), and mass spectrometry (MS) have been developed to identify and quantify antioxidant molecules in plant species (Covey et al., 1986). Kähkönen et al. (2001) indicate that there are many simple methods to extract fruit phenolic compounds (Escribano et al., 2006). Therefore, the choice of method is very important so that results are reliable and representative.

Considering the above-mentioned information, we can infer that it is important to generate information about antioxidants in Chile. Accordingly, the objective of this research study was to determine antioxidant capacity (AC), total anthocyanins (TA), and total phenols (TP) in wild and cultivated berries in different localities of $\mathrm{La}$ Araucanía and Los Ríos Regions, Chile.

\section{MATERIALS AND METHODS}

The research study was carried out in the Biochemistry and Phytopathology Laboratories of the Instituto de Agroindustria, Universidad de La Frontera in Temuco.

Fruit samples. Fruit was picked from adult plants of eight commercial and eight wild berry cultivars. Commercial berries corresponded to the following cultivars: three highbush blueberry (Vaccinium corymbosum L.), two raspberry (Rubus idaeus L.), two saskatoon (Amelanchier alnifolia (Nutt.) Nutt. ex M. Roem.), and one strawberry (Fragaria $\times$ ananassa Duchesne ex Rozier). The wild berries were sarsaparilla (Muehlenbeckia chilensis Meisn.), elderberry (Sambucus nigra L.), wild blackberry (Rubus ulmifolius Schott), Chilean guava (Ugni molinae Turcz.), rosehip (Rosa spp.), and maqui berry (Aristotelia chilensis (Molina) Stuntz). Table 1 shows the cultivars studied and the characteristics of the sampling sites.
Picking was carried out by direct harvesting of mature fruits in clamshell polyethylene terephthalate (PET) containers from plants with 40 to $60 \%$ fruit with optimal ripeness according to color. Picked fruit was transported to the Biochemistry Laboratory and stored according to use. Fruit analyzed before $7 \mathrm{~d}$ from harvest was maintained refrigerated at $4 \pm 1{ }^{\circ} \mathrm{C}$ whereas fruit destined for further analysis was preserved according to the individual quick freezing, IQF, method at $-20{ }^{\circ} \mathrm{C}$. Thawing of the fruit in IQF was gradual over $24 \mathrm{~h}$ in laboratory conditions so as to avoid cell lysis.

Reagents. Reagents were: monohydrated gallic acid, ethanol, methanol, cyanidin 3-glucoside, Folin-Ciocalteu reagent (Sigma Chemical, St. Louis, Missouri, USA), 2,2-diphenyl-1-picrylhydrazyl (DPPH), phosphate buffer (75 mM, pH 7 phosphate), deionized, distilled, and sterilized water.

Extraction. Homogenization of $10 \mathrm{~g}$ of fruit was done through maceration in a ceramic mortar and deionized water was added in a ratio of 1:2 w/v. The homogenate was centrifuged in a Beckman GS centrifuge (Beckman GS, Beckman Instruments, California, USA) at 31700 $\mathrm{g}$ for $15 \mathrm{~min}$ at $4{ }^{\circ} \mathrm{C}$ and the supernatant was separated (juice fraction). The pulp (insoluble fraction) was treated with $50 \mathrm{~mL}$ of pure ethanol solution (99\%). The homogenate was maintained at a controlled temperature $\left(25-30^{\circ} \mathrm{C}\right)$ and shaken every $2 \mathrm{~min}$ for $20 \mathrm{~min}$. It was then centrifuged at $31700 \mathrm{~g}$ for $15 \mathrm{~min}$ at $4{ }^{\circ} \mathrm{C}$. The supernatant was separated and the remaining insoluble fraction was washed again with $25 \mathrm{~mL}$ of pure methanol or ethanol solution which was combined with the previous extract and maintained at $4{ }^{\circ} \mathrm{C} \pm 1$.

Analysis of antioxidant capacity. A method based on the discoloration test of the radical 2,2-diphenyl-1picrylhydrazyl hydrate (DPPH) was employed to analyze AC in berries (Cao et al., 1996). Since no references were found in the literature on the use of the DPPH method in fresh berries, the amount of reactants and reaction time were adapted to evaluate AC.

The chemical analysis protocol of extraction phases and determination of AC, TA, and TP was standardized prior to final extraction. Protocol standardization was carried out with fruit of diverse highbush blueberry cultivars from different locations which were kept frozen in IQF at $-20^{\circ} \mathrm{C}$.

Determination of total anthocyanins. Total anthocyanin content of diluted fruit extract was estimated by the $\mathrm{pH}$ differential method proposed by Cheng and Breen (1991) and used by Prior et al. (1998), Wang and Lin 
Table 1. Sampling and picking location background information for wild and cultivated berries.

\begin{tabular}{|c|c|c|c|c|c|c|}
\hline Species & Cultivar & $\begin{array}{c}\text { Fruit } \\
\text { picking } \\
\text { month } \\
(2004)\end{array}$ & $\begin{array}{c}\text { Soil } \\
\text { series }\end{array}$ & Order & Texture & Classification $^{1}$ \\
\hline \multicolumn{7}{|c|}{ Cultivated berries } \\
\hline Blueberry & Elliot & January & Villarrica & Andisol & Sandy loam & Acrudoxic Melanudands \\
\hline Blueberry & Brighitta & February & Villarrica & Andisol & Sandy loam & Acrudoxic Melanudands \\
\hline Blueberry & Brightwell & January & Collipulli & Alfisol & Silt clay loam & Typic Rhodoxeralfs \\
\hline Raspberry & Meeker & February & La Unión & Inceptisol & $\begin{array}{l}\text { Sandy loam to } \\
\text { silt clay loam }\end{array}$ & Andic Dystrudepts \\
\hline Raspberry & Heritage & February & La Unión & Inceptisol & $\begin{array}{l}\text { Sandy loam to } \\
\text { silt clay loam }\end{array}$ & Andic Dystrudepts \\
\hline Saskatoon & Honeywood & March & Loncoche & Andisol & Silt loam & Acrudoxic Hapludands \\
\hline Saskatoon & Martin & March & Loncoche & Andisol & Silt loam & Acrudoxic Hapludands \\
\hline Strawberry & -- & February & Collipulli & Alfisol & Silt clay loam & Typic Rhodoxeralfs \\
\hline \multicolumn{7}{|l|}{ Wild berries } \\
\hline Sarsaparilla & Wild & March & La Unión & Inceptisol & $\begin{array}{l}\text { Sandy loam to } \\
\text { silt clay loam }\end{array}$ & Andic Dystrudepts \\
\hline Elderberry & Wild & February & La Unión & Inceptisol & $\begin{array}{l}\text { Sandy loam to } \\
\text { silt clay loam }\end{array}$ & Andic Dystrudepts \\
\hline Wild blackberry & Wild & March & Villarrica & Andisol & Sandy loam & Acrudoxic Melanudands \\
\hline Chilean guava & Wild & March & Villarrica & Andisol & Sandy loam & Acrudoxic Melanudands \\
\hline Rosehip & Wild & March & Collipulli & Alfisol & Silt clay loam & Typic Rhodoxeralfs \\
\hline Rosehip & Wild & March & Villarrica & Andisol & Sandy loam & Acrudoxic Melanudands \\
\hline Maqui berry & Wild & February & Freire & Andisol & Silt loam & Typic Placudands \\
\hline Maqui berry & Wild & February & Villarrica & Andisol & Sandy loam & Acrudoxic Melanudands \\
\hline
\end{tabular}

${ }^{1}$ Soil classification according to CIREN (1999) and US Soil Taxonomy (Soil Survey Staff, 2003).

(2000), Wang and Stretch (2001), as well as Zheng and Wang (2003). Absorbance was measured with a UVvisible spectrophotometer at 510 and $700 \mathrm{~nm}$ at $\mathrm{pH} 1$ and 4.5 where $\mathrm{A}=\left(\mathrm{A}_{510}-\mathrm{A}_{700}\right) \mathrm{pH} 1-\left(\mathrm{A}_{510}-\mathrm{A}_{700}\right) \mathrm{pH}$ 4.5. Data were calculated with the extinction coefficient for cyanidin-3-glucoside (29 600) and expressed as mg cyanidin $100 \mathrm{~g}^{-1}$ fresh weight.

Determination of total phenolic compounds. Total phenolic content in diluted fruit extract was measured by the Folin-Ciocalteu colorimetric procedure based on the formation of a blue molybdenum-tungsten complex with a gallic acid standard (Singleton and Rossi, 1965 as cited by Wang and Lin, 2000; Asami et al., 2003). Diverse authors (Heinonen et al., 1998a; 1998b; Prior et al., 1998; Kähkönen et al., 2001; Wang and Stretch, 2001; Asami et al., 2003; Zheng and Wang, 2003) have used this methodology to study TP in berries.

From 0.5 to $1 \mathrm{~mL}$ of the extract was mixed with $5 \mathrm{~mL}$ of deionized water and $1 \mathrm{~mL}$ of Folin-Ciocalteu reagent in a $25 \mathrm{~mL}$ volumetric flask and maintained for 5 to 8 $\mathrm{min}$ at room temperature. Subsequently, $10 \mathrm{~mL}$ of a $7 \%$ sodium carbonate solution was added to complete 25 $\mathrm{mL}$. The solution was mixed again and maintained for 2 $\mathrm{h}$ in laboratory conditions. Aliquots of this sample were filtered through a $0.45 \mu \mathrm{m}$ polytetrafluoroethylene filter (Whatman), and then total sample phenols were evaluated with a UV-visible spectrophotometer monitoring at 765 nm every 5 min. Total phenol content was standardized with gallic acid and expressed as $\mathrm{mg} \mathrm{L}^{-1}$ of gallic acid equivalent (GAE). The concentration correlation was established as a function of gallic acid for equal absorbance in a range of 0.5 to $5 \mathrm{mg} \mathrm{L}^{-1} \mathrm{GAE}\left(\mathrm{R}^{2}=0.99\right)$.

Experimental design and statistical analysis. Data obtained were analyzed on the basis of a random design with three replicates for each treatment and by ANOVA. Means were compared for the Tukey multiple comparison test $(\mathrm{p} \leq 0.05)$. A correlation analysis and linear regression were carried out to correlate AC with TP and TA. Data were processed by the StatsDirect v. 2.7.8 (StatsDirect, Cheshire, UK) statistical program. 


\section{RESULTS}

Antioxidant capacity, total anthocyanins, and total phenol content (Table 2) were determined for 10 species of berries (four cultivated and six wild) separated into nine groups according to antioxidant potential (Figure 1). DPPH (antioxidant capacity) discoloration percentages of the berries studied ranged between $67.8 \%$ for red sarsaparilla and $95.3 \%$ for rosehip, and with a total mean of $86.3 \%$. Antioxidant capacity of evaluated species was significantly correlated with TP $(0.70)$, but was not significant with TA content (0.01).

Maqui berry showed a significantly higher TA content (2240.2 and $1445.3 \mathrm{mg} \mathrm{L}^{-1}$ ) than the rest of the berries. Mean value of TA for all berries was $335.5 \mathrm{mg} \mathrm{L}^{-1}$. The highest levels of TP content were obtained in the two saskatoon (773.9 and 1001.9) and two rosehip (1457.0 and 1140.4) cultivars for which values were significantly higher than for other berries.

The berries studied were grouped according to their antioxidant potential in nine main groups by means of cluster analysis of the three parameters (Figure 1).
The three blueberry cultivars were grouped in cluster 4 along with raspberry cv. Heritage, Chilean guava, and red sarsaparilla. It was observed when comparing means among groups that antioxidant capacity of group 4 was significantly different from elderberry, raspberry cv. Meeker, strawberry, saskatoon cv. Martin, and maqui berry. However, it did not show any significant difference with saskatoon cv. Honeywood, rosehip, and wild blackberry (Figure 2A). Total anthocyanin content was significantly higher in saskatoon cv. Honeywood and rosehip (Groups 2 and 7) (Figure 2B). Total phenol content was significantly higher in saskatoon cv. Martin (Figure 2C) than in any of the berries studied.

\section{DISCUSSION}

A significant difference was found in AC, TP, and TA between studied species and between cultivars of the same species. These results could be explained by the high variability of substances with antioxidant characteristics present in the berries. Consequently, Atala et al. (2009) cite that blueberry fruit is flavonoid-rich (quercetin)

Table 2. Antioxidant capacity (AC), percentage discoloration (2,2-diphenyl-1-picrylhydrazyl), total anthocyanin content (TA, referred to $\mathrm{mg} \mathrm{L}^{-1}$ cyanidin 3-glucoside), total phenol content (TP, as $\mathrm{mg} \mathrm{L}^{-1}$ gallic acid) of wild and cultivated berries in La Araucanía and Los Ríos Regions, Chile.

\begin{tabular}{lccc}
\hline Species and cultivar & AC & TA & TP \\
\hline Cultivated berries & & & $429.6 \mathrm{gh}$ \\
Blueberry cv. Elliot & $82.5 \mathrm{~h}$ & $199.6 \mathrm{de}$ & $318.6 \mathrm{jk}$ \\
Blueberry cv. Brigitta & $76.0 \mathrm{j}$ & $122.1 \mathrm{efg}$ & $361.0 \mathrm{hij}$ \\
Blueberry cv. Brightwell & $84.9 \mathrm{f}$ & $149.6 \mathrm{def}$ & $521.4 \mathrm{f}$ \\
Raspberry cv. Meeker & $91.8 \mathrm{bc}$ & $52.4 \mathrm{gh}$ & $389.7 \mathrm{ghij}$ \\
Raspberry cv. Heritage & $82.6 \mathrm{gh}$ & $65.6 \mathrm{fgh}$ & $773.9 \mathrm{~d}$ \\
Saskatoon cv. Honeywood & $91.1 \mathrm{c}$ & $196.7 \mathrm{de}$ & $1001.9 \mathrm{c}$ \\
Saskatoon cv. Martin & $92.3 \mathrm{~b}$ & $213.6 \mathrm{~d}$ & $538.3 \mathrm{f}$ \\
Strawberry & $80.9 \mathrm{i}$ & $43.8 \mathrm{gh}$ & \\
Wild berries & & & $245.3 \mathrm{k}$ \\
Red Sarsaparilla & $67.8 \mathrm{k}$ & $11.9 \mathrm{~h}$ & $788.3 \mathrm{~d}$ \\
Elderberry & $91.4 \mathrm{bc}$ & $416.3 \mathrm{c}$ & $644.7 \mathrm{e}$ \\
Wild blackberry & $87.5 \mathrm{e}$ & $189.3 \mathrm{de}$ & $420.9 \mathrm{ghi}$ \\
Chilean guava & $90.0 \mathrm{~d}$ & $15.9 \mathrm{~h}$ & $1457.0 \mathrm{a}$ \\
Rosehip & $94.4 \mathrm{a}$ & $3.8 \mathrm{~h}$ & $1140.4 \mathrm{~b}$ \\
Rosehip & $95.3 \mathrm{a}$ & $3.2 \mathrm{~h}$ & $457.2 \mathrm{fg}$ \\
Maqui berry & $83.6 \mathrm{~g}$ & $2240.2 \mathrm{a}$ & $346.6 \mathrm{ij}$ \\
Maqui berry & $89.5 \mathrm{~d}$ & $1445.3 \mathrm{~b}$ & $\mathbf{6 1 4 . 7}$ \\
Mean & $\mathbf{8 6 . 3}$ & $\mathbf{3 3 5 . 5}$ & \\
\hline Correlation & & & 0.70 \\
AC & --- & 0.01 & -0.22 \\
TA & --- & --- & \\
\hline Difer & & & \\
\hline
\end{tabular}

Different letters among species according to treatment indicate a significant difference according to Tukey test $(\mathrm{P} \leq 0.05)$. 


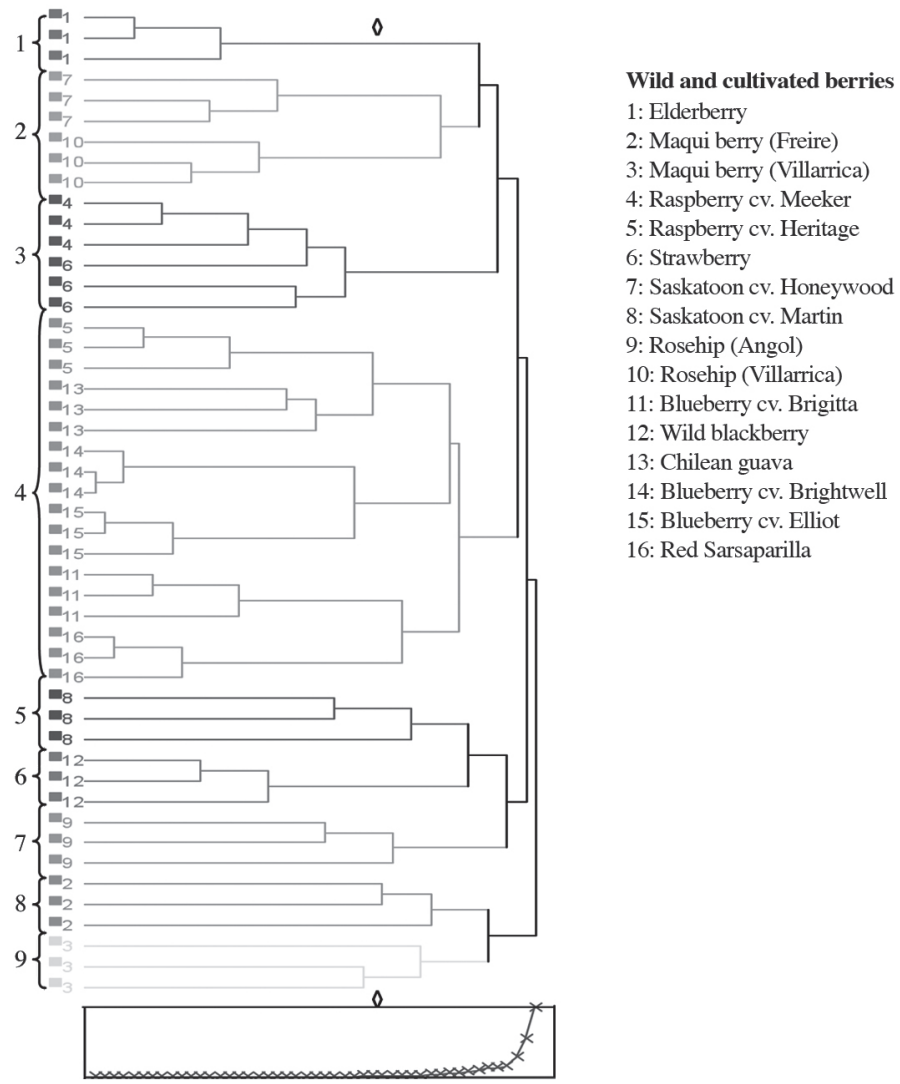

Figure 1. Similarity dendrogram of 16 wild and cultivated berries grown in Chile in relation to their antioxidant potential.

while strawberry and raspberry have higher ellagic acid content. In addition, blueberries are especially rich in hydroxycinnamic acid derivatives which have been shown to possess high antioxidant activity (Chen and Ho, 1997; Meyer et al., 1998; Slimestad and Solheim, 2002; Cheel et al., 2005; Parry et al., 2005; Araya et al., 2006; Rubilar et al., 2006).

The wild rosehip species was identified as having high AC in fruit picked in both Villarrica and Angol. In the cultivated species, the two saskatoon (Martin and Honeywood) and raspberry cv. Meeker cultivars were underscored. On the subject, Tsao et al. (2003) indicate that there is a big difference in phenol content among wild and cultivated varieties and is much greater in wild raspberries than in cultivated raspberries. Halvorsen et al. (2002) also found that wild blueberry has higher AC than cultivated species.

Ding et al. (2006) and Pantelidis et al. (2007) cite that TA in cultivated strawberry species, unlike wild species, can contribute more to AC than TP. They add that $\mathrm{AC}$ was positively correlated with $\mathrm{TP}$ and $\mathrm{TA}$ in cultivated berries but not in wild berries. Antioxidant capacity was significantly correlated with TP in this study but not with TA. Furthermore, the significant correlation between $\mathrm{AC}$ and $\mathrm{TP}$ recorded in this study coincides with values reported by Connor et al. (2002b) who suggest that phenols could be used as a measure for determining specific antioxidant molecules.

When comparing cultivars in the same locality, for example raspberry, it was determined that cv. Meeker showed significantly higher $\mathrm{AC}$, TP, and TA than $\mathrm{cv}$. Heritage. The latter showed differences attributable to genotype. A similar tendency was observed when comparing antioxidant capacity of two blueberry cultivars in the same locality. Likewise, differences were significant when comparing two blueberry species (highbush and rabbiteye) in distinct localities. Along this line, studies carried out by Hakkinen et al. (1999) on strawberry and blueberry reported significant differences in phenolic compound content, differences that were positively correlated with the cultivar and growing region. The same authors add that TP content varied a great deal. The more specific phenolic compound profile also recorded significant variations among harvested cultivars in distinct localities and among growing seasons, thus making it very difficult to clearly distinguish the factors causing these differences.

Howard et al. (2003) established a positive correlation 

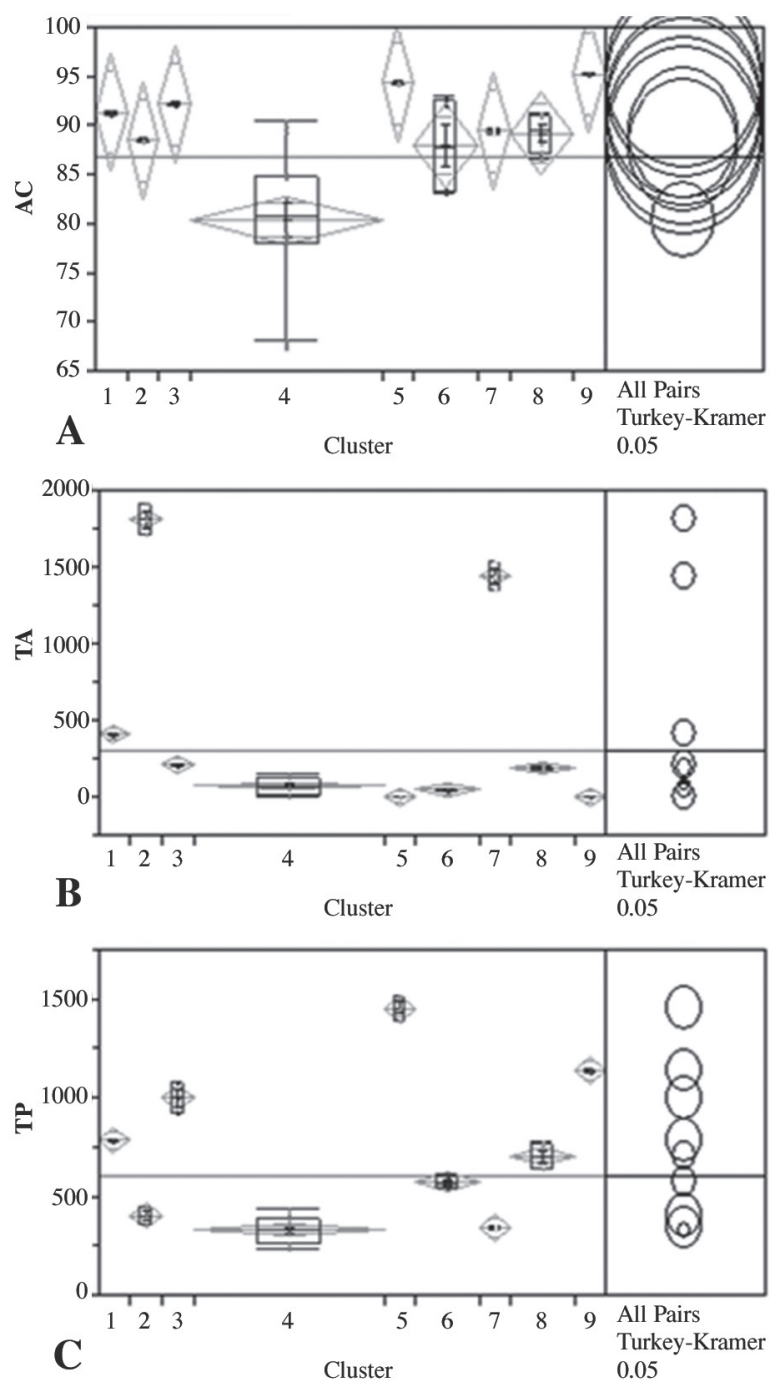

Figure 2. Multidimensional scale and statistical distance for: A) antioxidant capacity (AC); B) total anthocyanins (TA), and C) total phenolic content (TP).

between AC and TP, TA, tartaric ester, and flavonoids in two growth periods for various highbush blueberry cultivars. The evaluated germplasm was more affected by cultivar and cultivar $\mathrm{x}$ growing season interaction than by the growing season itself. The content of TA between the two growing seasons indicates that TA synthesis was affected more by differences in environmental growth conditions. It can be inferred from this that cultivars having a higher TP content could be selected to increase $\mathrm{AC}$ and that it would be convenient to evaluate the cultivars in various growing seasons.

Regarding the influence of environmental conditions in the crop site, diverse authors report a variation in AC of berries among localities and years for a single crop site (Connor et al., 2002a; Howard et al., 2003). The effect of this crop practice is an aspect which also influences AC in blueberry. Accordingly, Asami et al. (2003) found that AC was lower for blueberries cultivated in a traditional way rather than organically. The authors attribute this response to the fact that plants in organic production are in an increased environmental stress condition.

\section{CONCLUSIONS}

There are significant differences in antioxidant capacity in wild and cultivated fruits in Chile, and a strong correlation between antioxidant capacity and total phenol content was observed. Of all the berries evaluated in this study, rosehip picked in the localities of Villarica and Angol was underscored for its antioxidant capacity. The cultivated berries with the greatest antioxidant capacity were the two saskatoon (Martin and Honeywood) and the raspberry cv. Meeker cultivars. From these study results, future studies are directed to evaluating the effect of climatic and edaphic conditions of different locations in Southern Chile on the antioxidant potential of cultivated and wild berries with greater antioxidant capacity, as well as the effect of agronomic management on the antioxidant capacity of different cultivars of the same species.

\section{ACKNOWLEDGEMENTS}

The authors thank the DIUFRO 120417 Project of the Dirección de Investigación y Desarrollo, Universidad de La Frontera for financing this research.

\section{RESUMEN}

Capacidad antioxidante, antocianinas y fenoles totales de berries silvestres y cultivados en Chile. Por medio del consumo de berries es posible incorporar al organismo una gran cantidad de antioxidantes capaces de prevenir múltiples enfermedades generadas por la acción de los radicales libres. Los antioxidantes actúan neutralizando los radicales libres y de esta forma protegen al organismo del daño oxidativo de lípidos, proteínas y ácidos nucleicos. Entre variadas frutas y hortalizas, se destacan los berries como una de las fuentes más ricas en fitonutrientes antioxidantes. El objetivo de esta investigación fue determinar la capacidad antioxidante (AC), antocianinas totales (TA) y el contenido de fenoles totales (TP), de berries silvestres y cultivados en diferentes localidades de la Región de La Araucanía y Región de Los Ríos (Chile). Para evaluar estos parámetros se utilizó el método de radicales libres 2,2-difenil-2- picrilhidrazilo (DPPH), $\mathrm{pH}$ diferencial y Folin-Ciocalteu, respectivamente. Los porcentajes de decoloración del DPPH estuvieron 
comprendidos entre $67,8 \%$ para zarzaparrilla roja y $95,3 \%$ para rosa mosqueta. El maqui presentó un contenido de AT significativamente mayor (2240,2 y $1445,3 \mathrm{mg} \mathrm{L}^{-1}$ cianidina 3-glucósido) que el resto de los berries, el promedio de AT fue de $335,5 \mathrm{mg} \mathrm{L}^{-1}$. En cuanto al contenido FT los mayores niveles se obtuvieron en los dos cultivares de saskatoon (773,9 y $1001,9 \mathrm{mg} \mathrm{L}^{-1}$ ácido gálico) y en rosa mosqueta silvestre (1457,0 y 1140,4 mg L-1 de ácido gálico). En este estudio se concluye que existen diferencias significativas en la capacidad antioxidante de frutos silvestres y cultivados en Chile, observándose una fuerte correlación entre el CA y el contenido de FT.

Palabras clave: Vaccinium corymbosum, 2,2-diphenyl-1picrylhydrazyl, potencial antioxidante.

\section{LITERATURE CITED}

Araya, H., C. Clavijo, y C. Herrera. 2006. Capacidad antioxidante de frutas y verduras cultivadas en Chile. Archivos Latinoamericanos de Nutrición 56:361-365.

Asami, D., Y. Hong, D. Barret, and A. Mitchell. 2003. Comparison of the total phenolic and ascorbic acid content of freeze-dried and air-dried marionberry, strawberry, and corn grown using conventional, organic, and sustainable agricultural practices. Journal of Agricultural and Food Chemistry 51:1237-1241.

Atala, E., L. Vásquez, H. Speisky, E. Lissi, and C. López-Alarcón. 2009. Ascorbic acid contribution to ORAC values in berry extracts: An evaluation by the ORAC-pyrogallol red methodology. Food Chemistry 113:331-335.

Cao, G., E. Sofic, and R. Prior. 1996. Antioxidant capacity of tea and common vegetables. Journal of Agricultural and Food Chemistry 44:3426-3431.

CIREN. 1999. Descripción de suelos; materiales y símbolos. Estudio Agrológico IX Región. Publicación CIREN No 122. 326 p. Centro de Información de Recursos Naturales (CIREN), Santiago, Chile.

Connor, A.M., Ch. Finn, and J. Hancock. 2002a. Genotypic and environmental variation in antioxidant activity, total phenolic content, and anthocyanin content among blueberry cultivars. Journal of the American Society of Horticultural Science 127:89-97.

Connor, A., J. Luby, and C. Tong. 2002b. Variability in antioxidant activity in blueberry and correlations among different antioxidant activity assays. Journal of the American Society of Horticultural Science 127: 238-244.

Covey, Th., E. Lee, A. Bruins, and J. Henion. 1986. Liquid chromatography/mass spectrometry. Analytical Chemistry 58:1451A-1661A.
Cheel, J., C. Theoduloz, J. Rodriguez, G. Saud, P. Caligari, and G. Schmeda-Hirschmann. 2005. E-Cinnamic acid derivatives and phenolics from Chilean strawberry fruits, Fragaria chiloensis ssp. chiloensis. Journal of Agricultural and Food Chemistry 53:8512-8518.

Chen, J., and C. Ho. 1997. Antioxidant activities of caffeic acid and its related hydroxycinnamic acid compounds. Journal of Agricultural and Food Chemistry 45:23742378.

Cheng, G., and P. Breen. 1991. Activity of phenylalanine ammonia-lyase (PAL) and concentrations of anthocyanins and phenolics in developing strawberry fruit. Journal of the American Society of Horticultural Science 116:865-869.

Ding, M., R. Feng, Sh. Wang, L. Bowman, Y. Lu, Y. Qian, V. Castranova, B. Jiang, and X. Shi. 2006. Cyanidin-3glucoside, a natural product derived from blackberry, exhibits chemopreventive and chemotherapeutic activity. Journal of Biological Chemistry 281:17359-17368.

Escribano, M.T., C. Alcalde, O. Muñoz, J. Rivas, and C. Santos. 2006. Anthocyanins in berries of maqui (Aristotelia chilensis (Mol.) Stuntz). Phytochemical Analysis 17:8-14.

Gil, M., F. Tomas-Barberan, B. Hess-Pierce, and A. Kader. 2002. Antioxidant capacities, phenolic compounds, carotenoids, and vitamin $\mathrm{C}$ contents of nectarine, peach, and plum cultivars from California. Journal of Agricultural and Food Chemistry 50:4976-4982.

Hakkinen, S., S. Karenlampi, M. Heinonen, H. Mykkanen, and A. Torronen. 1999. Content of the flavonols quercetin, myricetin, and kaempferol in 25 edible berries. Journal of Agricultural and Food Chemistry 47:2274-2279.

Halvorsen, B., Holte, K., Myhrstad, M. Barykmo, I., Hvattum, I., Remberg, et al. 2002. A systematic screening of total antioxidants in dietary plants. Journal of Nutrition 132:461-471.

Halliwell, B. 2007. Oxidative stress and cancer: have we moved forward? Biochemistry Journal 401:1-11.

Heinonen, I., A. Meyer, and E. Frankel. 1998a. Antioxidant activity of berry and fruit wines and liquors. Journal of Agricultural and Food Chemistry 46:25-31.

Heinonen, I., A. Meyer, and E. Frankel. 1998b. Antioxidant activity of berry phenolics on human lowdensity lipoprotein and liposome oxidation. Journal of Agricultural and Food Chemistry 46:4107-4112.

Hertog, M., P. Hollman, and B. Van de Putte. 1993. Content of potentially anticarcinogenic flavonoids of tea infusions, wines, and fruit juices. Journal of Agricultural and Food Chemistry 41:1242-1246.

Hollman, P.C.H., and M.B. Katan. 1999. Dietary flavonoids: intake, health effects and bioavailability. Food and Chemical Toxicology 37(9-10):937-942. 
Howard, L.R., J.R. Clark, and C. Brownmiller. 2003. Antioxidant capacity and phenolic content in blueberries as affected by genotype and growing season. Journal of the Science of Food and Agriculture 83:1238-1247.

Kähkönen, M., A. Hopia, and M. Heinonen. 2001. Berry phenolics and their antioxidant activity. Journal of Agricultural and Food Chemistry 49:4076-4082.

Meyer, A., J. Donovan, D. Pearson, A. Waterhouse, and E. Frankel. 1998. Fruit hydroxycinnamic acids inhibit human low-density lipoprotein oxidation in vitro. Journal of Agricultural and Food Chemistry 46:17831787.

Moure, A., J. Cruz, D. Franco, J. Domínguez, J. Sineiro, H. Domínguez, M. Núñez, and J. Parajó. 2000. Natural antioxidants from residual sources. Food Chemistry 72:145-171.

Pantelidis, G.E., M. Vasilakakis, G.A. Manganaris, and G. Diamantidis. 2007. Antioxidant capacity, phenol, anthocyanin and ascorbic acid contents in raspberries, blackberries, red currants, gooseberries and Cornelian cherries. Food Chemistry 102:777-783.

Parry, J., L. Su, M. Luther, K. Zhou, M.P. Yurawecz, P. Whittaker, and Ll. Yu. 2005. Fatty acid composition and antioxidant properties of cold-pressed marionberry, boysenberry, red raspberry, and blueberry seed oils. Journal of Agricultural and Food Chemistry 53:566-573.

Prior, R., G. Cao, A. Martin, E. Sofic, J. McEwen, Ch. O'Brien, et al. 1998. Antioxidant capacity as influenced by total phenolic and anthocyanin content, maturity, and variety of Vaccinium species. Journal of Agricultural and Food Chemistry 46:2686-2693.

Roberts, W., and M. Gordon. 2003. Determination of the total antioxidant activity of fruits and vegetables by a liposome assay. Journal of Agricultural and Food Chemistry 51:1486-1493.

Rubilar, M., M. Pinelo, M. Ihl, E. Scheuermann, J., Sineiro, and M.J. Nuñez. 2006. Murta leaves (Ugni molinae Turcz) as a source of antioxidant polyphenols. Journal of Agricultural and Food Chemistry 54:59-64.

Seeram, N. 2008a. Berry fruits: Compositional elements, biochemical activities, and the impact of their intake on human health, performance, and disease. Journal of Agricultural and Food Chemistry 56:627-629.

Seeram, N. 2008b. Berry fruits for cancer prevention: Current status and future prospects. Journal of Agricultural and Food Chemistry 56:630-635.

Seeram, N., L. Adams, Y. Zhang, R. Lee, D. Sand, H. Scheuller, and D. Heber. 2006. Blackberry, black raspberry, blueberry, cranberry, red raspberry, and strawberry extracts inhibit growth and stimulate apoptosis of human cancer cells in vitro. Journal of Agricultural and Food Chemistry 54:9329-9339.
Slimestad, R. and H. Solheim. 2002. Anthocyanins from black currants (Ribes nigrum L.). Journal of Agricultural and Food Chemistry 50:3228-3231.

Soil Survey Staff. 2003. Keys to soil taxonomy. $9^{\text {th }}$ ed. 332 p. United States Department of Agriculture - Natural Resources Conservation Service (USDA-NRCS), Washington DC., USA.

Speisky, H., A. Pena, M. Gomez, C. Fredes, M. Hurtado, M. Gotteland, and O. Brunser. 2008. Antioxidants in Chilean berries. IX International Rubus and Ribes Symposium, Pucón, Chile. Acta Horticulturae 777:485-492.

Su, M., and P. Chien. 2007. Antioxidant activity, anthocyanins, and phenolics of rabbiteye blueberry (Vaccinium ashei) fluid products as affected by fermentation. Food Chemistry 104:182-187.

Tsao, R., R. Yang, E. Sockovie, T. Zhou, and A. Dale. 2003. Antioxidant phytochemicals in cultivated and wild Canadian strawberries. Acta Horticulturae 626:25-35.

Wada, L., and O. Boxin. 2002. Antioxidant activity and phenolic content of Oregon caneberries. 2002. Antioxidant activity and phenolic content of Oregon Caneberries. Journal of Agricultural and Food Chemistry 50:3495-3500.

Wang, Sh., G. Cao, and R. Prior. 1996. Total antioxidant capacity of fruits. Journal of Agricultural and Food Chemistry 44:701-705.

Wang, Sh., G. Cao, and R. Prior. 1997. Oxygen radical absorbing capacity of anthocyanins. Journal of Agricultural and Food Chemistry 45:304-309.

Wang, Sh., and H. Lin. 2000. Antioxidant activity in fruits and leaves of blackberry, raspberry, and strawberry varies with cultivar and developmental stage. Journal of Agricultural and Food Chemistry 48:140-146.

Wang, Sh., and A. Stretch. 2001. Antioxidant capacity in cranberry is influenced by cultivar and storage temperature. Journal of Agricultural and Food Chemistry 49:969-974.

Zheng, W., and Sh. Wang. 2003. Oxygen radical absorbing capacity of phenolics in blueberries, cranberries, chokeberries, and lingonberries. Journal of Agricultural and Food Chemistry 51:2122-2127.

Zheng, Y., Ch. Wang, Sh. Wang, and W. Zheng. 2003. Effect of high oxygen atmospheres on blueberry phenolics, anthocyanins, and antioxidant capacity. Journal of Agricultural and Food Chemistry 51:71627169 . 